\title{
'Earlibrite' Strawberry
}

\author{
C.K. Chandler ${ }^{1}$, D.E. Legard ${ }^{2}$, and D.D. Dunigan ${ }^{3}$ \\ Gulf Coast Research and Education Center, University of Florida, 13138 Lewis \\ Gallagher Road, Dover, FL 33527
}

\section{T.E. Crocker ${ }^{4}$}

\section{Horticultural Sciences Department, University of Florida, Gainesville, FL 32611-0690}

\section{C.A. Sims 5}

Food Science and Human Nutrition Department, University of Florida, Gainesville, FL 32611-0690

Additional index words. Fragaria $\times$ ananassa, fruit breeding

There is a need in west central Florida and other winter strawberry (Fragaria $\times$ ananassa Duchesne) production areas for an early ripening cultivar to replace or be an alternative to 'Sweet Charlie' (Chandleret al., 1997a). 'Sweet Charlie' has benefitted the Florida strawberry industry through its relatively high production of fruit early in the season, when market prices are generally high. But the average fruit size is small, and the texture of its fruit is often soft, making shipment and shelf life of 'Sweet

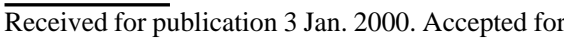
publication 31 May 2000. Florida Agricultural Experiment Station Journal Series no. R-07299. The cost of publishing this paper was defrayed in part by the payment of page charges. Under postal regulations, this paper therefore must be hereby marked advertisement solely to indicate this fact.

${ }^{1}$ Associate Professor of Horticultural Sciences. E-mail address: ckc@gnv.ifas.ufl.edu

${ }^{2}$ Assistant Professor of Plant Pathology.

${ }^{3}$ Research Scientist, Biotechnology.

${ }^{4}$ Professor of Horticultural Sciences.

${ }^{5}$ Professor of Food Science and Human Nutrition.
Charlie' problematic. 'Earlibrite' strawberry has produced high early-season (December through February) yields of large, flavorful fruit at the Univ. of Florida's Gulf Coast Research andEducation Center in Dover(GCRECDover) and in three commercial fields in westcentral Florida. It is recommended for trial in areas with mild winter climates. The clone was named 'Earlibrite' because of its high earlyseason production of bright red fruit, and to honor Earl Albregts, a soil scientist who spent his entire professional career (1967-96) at GCREC-Dover.

\section{Origin}

'Earlibrite' originated from a 1993 cross between 'Rosa Linda' (Chandler et al., 1997b) and FL 90-38 (Fig. 1). 'Rosa Linda', a 1996 release from the Florida Agricultural Experiment Station, was used as a parent because of its high early-season yield potential and its desirable fruit shape. FL 90-38, a 1991 selection, was used as a parent primarily because of its ability to produce attractive fruit early in the season. The original plant of 'Earlibrite' was selected in 1993 from a field nursery at GCRECDover. 'Earlibrite', tested as selection FL 93100 , has been evaluated in replicated plot trials at this location and in observational trials for several years at the Univ. of Florida's Suwannee Valley Research and Education Center, Live Oak, in north central Florida. Replicated plot trials were limited to only one location because most of Florida's 2500 ha of strawberries are within a $30-\mathrm{km}$ radius of the Dover center [Florida Agricultural Statistics (www.nass. usda.gov/fl)]. Strawberries in Florida are grown using the annual hill cultural system (Hancock, 1999). In the replicated trials at Dover, fresh transplants with leaves intact were planted each October through black polyethylene mulch on two-row raised beds. Beds were fumigated with a mixture of methyl bromide (98\%) and chloropicrin (trichloronitromethane) (2\%) prior to planting. Three plots (1995) or four plots (1996 and 1997) of each clone, were planted in a randomized complete-block design. Plots contained 10plants in the 1995-96 and 1997-98 seasons, and 16 plants in the 1996-97 season. Plants were spaced $38 \mathrm{~cm}$ apart in the row, with $30 \mathrm{~cm}$ between rows. Ripe fruit were harvested, graded, counted, and weighed twice a week from December through March. Each season's data were analyzed separately because of cultivar, planting date, and plant source differences between seasons. For sensory analysis, ripe fruit was harvested in the morning, cooled to $2{ }^{\circ} \mathrm{C}$, and transported to the Food Science and Human Nutrition Dept. in Gainesville. Trained panelists evaluated samples for color uniformity, strawberry flavor intensity, sweetness, and firmness, as described by Sims et al. (1997). Samples were evaluated from two harvest dates (February and March) in 1997, and three harvest dates (January, February, and March) in 1998.

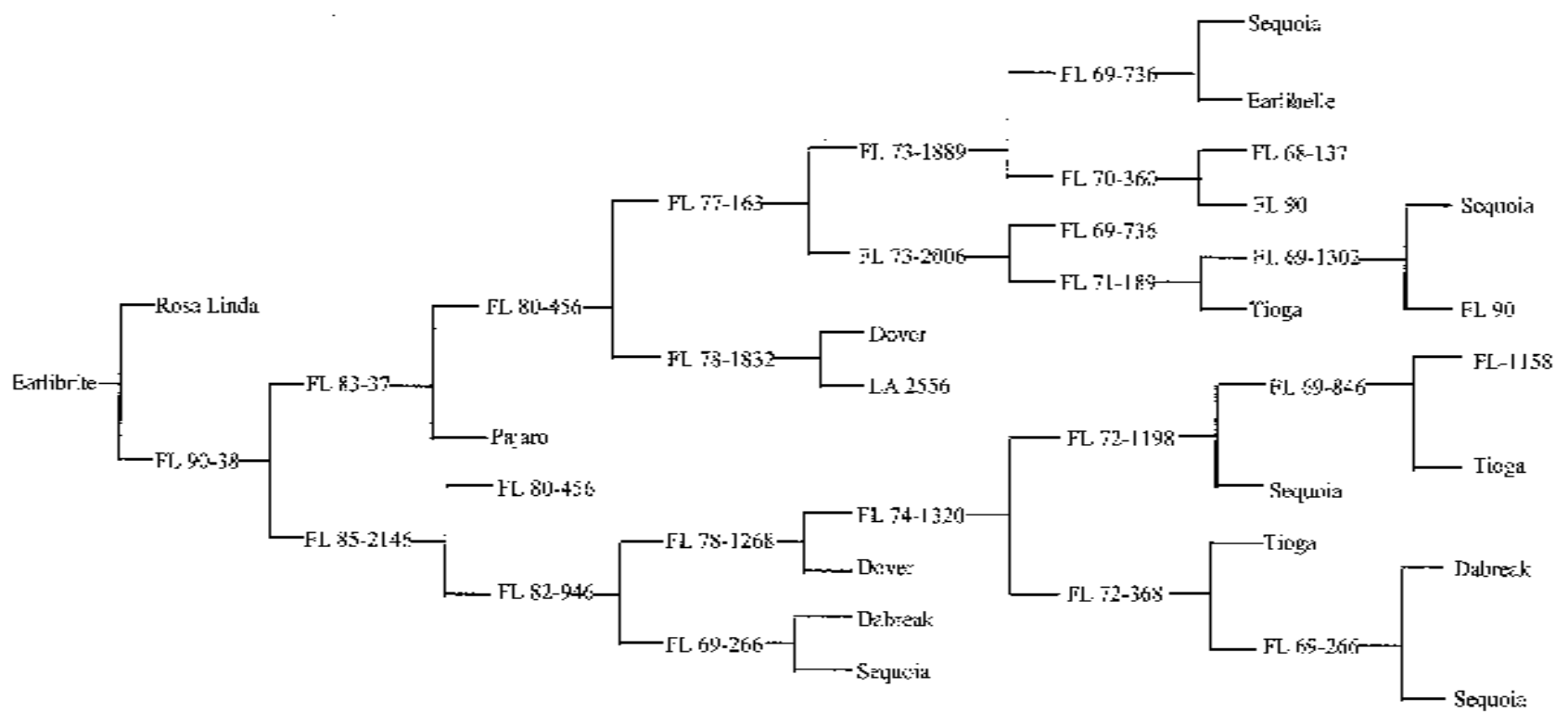

Fig. 1. Pedigree of 'Earlibrite' strawberry. 
Table 1. Performance of 'Earlibrite' strawberry compared with two standard cultivars grown at Dover, Fla. ${ }^{\mathrm{z}}$

\begin{tabular}{|c|c|c|c|c|c|c|}
\hline \multirow[b]{2}{*}{ Cultivar } & \multicolumn{5}{|c|}{ Marketable yield ${ }^{\mathrm{y}}$ (g/plant) } & \multirow[b]{2}{*}{$\mathrm{Wt}_{\text {fruit }}{ }^{\mathrm{x}}(\mathrm{g})$} \\
\hline & December & January & February & March & Total & \\
\hline \multicolumn{7}{|c|}{$1995-96$} \\
\hline Earlibrite & $0 \mathrm{~b}^{\mathrm{w}}$ & $109 \mathrm{a}$ & $256 \mathrm{a}$ & $122 \mathrm{a}$ & $488 \mathrm{a}$ & $27.0 \mathrm{a}$ \\
\hline Sweet Charlie & $18 \mathrm{a}$ & $84 \mathrm{a}$ & $174 \mathrm{ab}$ & $178 \mathrm{a}$ & $454 \mathrm{a}$ & $17.1 \mathrm{c}$ \\
\hline Oso Grande & $0 \mathrm{~b}$ & $84 \mathrm{a}$ & $87 \mathrm{~b}$ & $174 \mathrm{a}$ & $344 \mathrm{a}$ & $23.1 \mathrm{~b}$ \\
\hline \multicolumn{7}{|c|}{ 1996-97 } \\
\hline Earlibrite & $115 \mathrm{a}$ & $120 \mathrm{a}$ & $266 \mathrm{a}$ & $71 \mathrm{~b}$ & $572 \mathrm{a}$ & $21.7 \mathrm{a}$ \\
\hline Sweet Charlie & $73 \mathrm{~b}$ & $98 \mathrm{a}$ & $250 \mathrm{a}$ & $62 b$ & $483 \mathrm{a}$ & $17.8 \mathrm{c}$ \\
\hline Camarosa & $77 \mathrm{~b}$ & $131 \mathrm{a}$ & $212 \mathrm{a}$ & $137 \mathrm{a}$ & $557 \mathrm{a}$ & $20.2 \mathrm{~b}$ \\
\hline \multicolumn{7}{|c|}{ 1997-98 } \\
\hline Earlibrite & $66 \mathrm{~b}$ & $110 \mathrm{a}$ & $189 \mathrm{ab}$ & $280 \mathrm{~b}$ & $645 a$ & $20.7 \mathrm{a}$ \\
\hline Sweet Charlie & $91 \mathrm{a}$ & $54 \mathrm{~b}$ & $219 \mathrm{a}$ & $257 \mathrm{~b}$ & $622 \mathrm{a}$ & $17.6 \mathrm{~b}$ \\
\hline Camarosa & $50 \mathrm{~b}$ & $105 \mathrm{a}$ & $167 \mathrm{~b}$ & $426 \mathrm{a}$ & $748 \mathrm{a}$ & $20.0 \mathrm{a}$ \\
\hline
\end{tabular}

${ }^{2}$ Transplants were obtained from the following nursery locations: 'Earlibrite' from Florida in 1995 and 1997, and Quebec in 1996; 'Sweet Charlie' from Ontario in 1995, Quebec in 1996, and Florida in 1997; 'Oso Grande' from Ontario; and 'Camarosa' from Ontario in 1996, and North Carolina in 1997. Planting dates were 9 Nov. 1995, 15 Oct. 1996, and 9 Oct. 1997.

${ }^{y}$ Values represent mean per plant yield for three 10-plant plots in 1995-96, four 16-plant plots in 1996-97, and four 10-plant plots in 1997-98.

${ }^{\mathrm{x}}$ Mean fruit weight was determined by dividing total marketable fruit yield per plot by total marketable fruit number per plot.

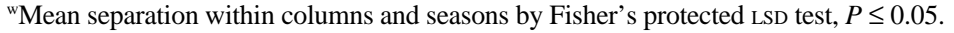

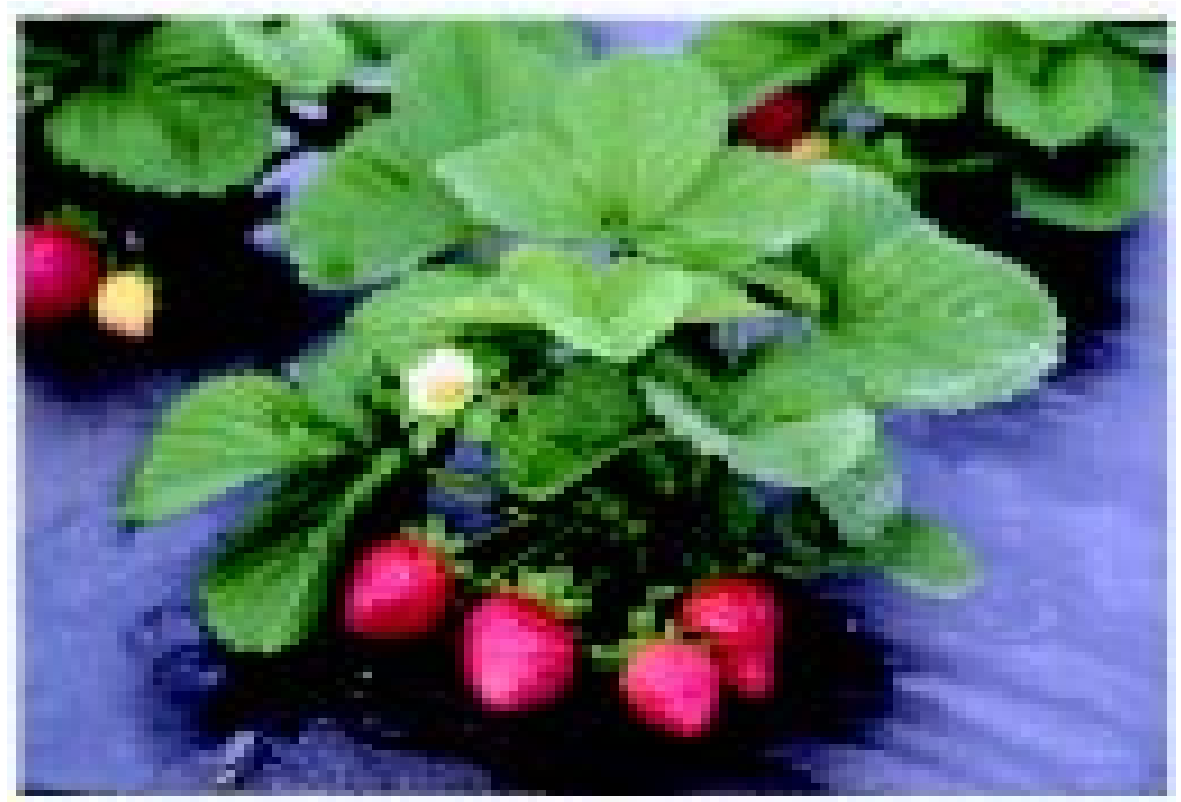

Fig. 2. 'Earlibrite' strawberry.

Table 2. Sensory characteristics of 'Earlibrite' strawberry fruit compared with that of two standard cultivars grown at Dover, Fla. ${ }^{2}$

\begin{tabular}{lcccc}
\hline \hline Cultivar & $\begin{array}{c}\text { Color } \\
\text { uniformity }\end{array}$ & $\begin{array}{c}\text { Flavor } \\
\text { intensity }\end{array}$ & Sweetness $^{\mathrm{y}}$ & Firmness $^{\mathrm{y}}$ \\
\hline Earlibrite & $9.5(1.9)$ & $1996-97$ & & \\
Sweet Charlie & $9.5(1.5)$ & $6.9(1.25)$ & $6.7(1.05)$ & $7.7(0.10)$ \\
Camarosa & $11.1(0.25)$ & $8.5(0.05)$ & $6.4(1.0)$ & $6.4(0.35)$ \\
& & $1997-98$ & & $10.2(0.8)$ \\
Earlibrite & $8.9(0.33)$ & $8.2(0.64)$ & $7.3(0.69)$ & $10.2(0.32)$ \\
Sweet Charlie & $9.9(0.42)$ & $7.8(0.54)$ & $7.2(0.53)$ & $8.2(0.57)$ \\
Camarosa & $9.7(0.79)$ & $7.5(0.35)$ & $6.0(0.26)$ & $11.7(0.62)$ \\
\hline
\end{tabular}

${ }^{2}$ Means and (SEs) based on the ratings of 12 to 15 trained panelists who rated samples of fruit from each cultivar twice in 1997 and three times in 1998.

${ }^{y}$ Rating scale 1 to 15 , with a higher score indicating more uniform color, more strawberry flavor intensity, more sweetness, and more firmness.

\section{Description}

'Earlibrite' is a short-day cultivar. It has a more compact plant habit than 'Sweet Charlie' or 'Camarosa' (U.S. plant patent no. 8708), currently the standard strawberry cultivars grown in west-central Florida. Average petiole length is $108 \mathrm{~mm}$. Average length and breadth is 81 and $71 \mathrm{~mm}$, respectively, for terminal leaflets, and 75 and $72 \mathrm{~mm}$, respectively for secondary ones. Leaflet margins are crenate and average 23 serrations per leaflet. The compact plant habit leads to the production of fruit that are exposed, and therefore easy to harvest. This exposure, however, also makes the fruit vulnerable to rain damage (i.e. cracking and cat-facing). Pedicels attached to mature primary fruit are 125 to $167 \mathrm{~mm}$ long, with branching of the inflorescence occurring close to the crown. Fruit of 'Earlibrite' tend to be very large; average weight of marketable fruit was over $20 \mathrm{~g}$ in trials at GCREC-Dover (Table 1). Large fruit size is an important breeding objective, and a key factor in the improvement of harvest efficiency (Rosati, 1993). Primary fruit are often globose-conic in shape, whereas secondary and tertiary fruit are conic to wedgeshaped (Fig. 2). External fruit color is a deeporange red and internal color is an orange-red (1805 and Pantone Warm Red, respectively, in the Pantone ${ }^{\circledR}$ Color Formula Guide). The calyx is generally medium in size and slightly recurved, a feature that may provide some structural resistance to Botrytis fruit rot (caused by Botrytis cinerea Pers.ex Fr.). Fruit of 'Earlibrite' are moderately firm and have a flavor intensity and sweetness comparable to 'Sweet Charlie' and 'Camarosa', as determined by a trained taste panel (Table 2). 'Earlibrite' also has some of the aromatic qualities of its parent 'Rosa Linda'.

\section{Performance}

In the replicated trials at GCREC-Dover, 'Earlibrite' produced total yields not significantly different than those of the standard cultivars (Table 1); in the 1996-97 trial, December fruit yield was significantly higher than 'Sweet Charlie' and 'Camarosa'. The 1996-97 trial was the only trial reported in Table 1 where the plants of 'Earlibrite', 'Sweet Charlie', and 'Camarosa' all came from the same general nursery area. Nursery location can influence early fruit yield in the Florida winter production system (Chandler et al., 1989). Early season fruit yields of 'Earlibrite' grown in three commercial fields in the Dover/Plant City area during the 1999-2000 season were comparable to those of 'Sweet Charlie'. 'Earlibrite' has also been an early producer of large fruit in the observational plots in north Florida, but in this location it generally lacks vigor and is less productive than 'Camarosa' or 'Chandler'.

'Earlibrite' is susceptible to anthracnose fruit rot (caused by Colletotrichum acutatum Simmonds), but, in most years, this disease has not been a serious problem. We anticipate that growers will finish harvesting 'Earlibrite' in early March, which is typically before environmental conditions are favorable for disease 
development. 'Earlibrite' appears to be less susceptible than 'Sweet Charlie' to Botrytis fruit rot and less susceptible than 'Camarosa' to powdery mildew (caused by Sphaerotheca macularis [Wallr.:Fr.] Jacz. F. sp. Fragariae Peries). 'Earlibrite' can, however, be severely affected by the twospotted spider mite (Tetranychus urticae Koch).

\section{Availability}

The Florida Agricultural Experiment Station at the Univ. of Florida's Institute of Food and Agricultural Sciences has applied for a U.S. plant patent on 'Earlibrite', and this cultivar has been uniquely characterized using a set of oligonucleotide DNA primers in randomly amplified polymorphic DNA (RAPD) analysis. 'Earlibrite' is licensed to the Florida Strawberry Growers Association by Florida Foundation Seed Producers, Inc. Information on nurseries sub-licensed to propagate 'Earlibrite' can be obtained from the Florida Strawberry Growers Association, P.O. Drawer 2550, Plant City, FL 33564.

\section{Literature Cited}

Chandler, C.K., E.E. Albregts, C.M. Howard, and J.K. Brecht. 1997. 'Sweet Charlie' strawberry. HortScience 32:1132-1133.
Chandler, C.K., E.E. Albregts, C.M. Howard, and A. Dale. 1989. Influence of propagation site on the fruiting of three strawberry clones grown in a Florida winter production system. Proc. Fla. State Hort. Soc. 102:310-312.

Chandler, C.K. D.E. Legard, and C.A. Sims. 1997. 'Rosa Linda' strawberry. HortScience 32:11341135.

Hancock, J.F. 1999. Strawberries. CAB Intl., New York.

Rosati,P. 1993. Recent trends in strawberry production and research: An overview. Acta Hort. 348:2344.

Sims, C.A., C.K. Chandler, J.S. Eastridge, and R.R. Golaszewski. 1997. Seasonal changes in fruit quality of several strawberry genotypes grown in Florida. Adv. Strawberry Res. 16:48-56 